\title{
Polymerase chain reaction using conjunctival swab samples for detecting Leishmania DNA in dogs
}

\author{
Reação em cadeia da polimerase usando amostras de Swab de conjuntiva \\ para detecção de DNA de Leishmania em cães
}

\begin{abstract}
Karen Araújo Magalhães ${ }^{1}$; Kamily Fagundes Pussi²; Hélton Krisman de Araújo'; Silvia Barbosa do Carmo; Elisabete Friozi3; Lidiane Schultz Branquinho4; Manoel Sebastião da Costa Lima Junior ${ }^{5 *}$ (1);
\end{abstract} Herintha Coeto Neitzke-Abreu ${ }^{4,6 *}$ (D)

\footnotetext{
${ }^{1}$ Curso de Medicina, Faculdade de Ciências da Saúde, Universidade Federal da Grande Dourados - UFGB, Dourados, MS, Brasil ${ }^{2}$ Curso de Biotecnologia, Faculdade de Ciências Biológicas e Ambientais, Universidade Federal da Grande Dourados - UFGB, Dourados, MS, Brasil

${ }^{3}$ Centro de Controle de Zoonoses, Campo Grande, MS, Brasil

${ }^{4}$ Programa de Pós-graduação em Ciências da Saúde, Universidade Federal da Grande Dourados - UFGB, Dourados, MS, Brasi ${ }^{5}$ Instituto Aggeu Magalhães, Fundação Oswaldo Cruz, Recife, PE, Brasil

${ }^{6}$ Faculdade de Ciências da Saúde, Universidade Federal da Grande Dourados - UFGB, Dourados, MS, Brasil
}

\begin{abstract}
How to cite: Magalhães KA, Pussi KF, de Araújo HK, do Carmo SB, Friozi E, Branquinho LS, et al. Polymerase chain reaction using conjunctival swab samples for detecting Leishmania DNA in dogs. Braz J Vet Parasitol 2021; 30(3): e009121. https://doi. org/10.1590/S1984-29612021061
\end{abstract}

\begin{abstract}
The dog is the main domestic reservoir of Leishmania and font of infection for the vector, constituting an important host for the transmission of the parasite to humans. Non-invasive collection of swab samples for leishmaniasis diagnosis has been a promising alternative. This study analyzed the positivity of polymerase chain reaction (PCR) for the diagnosis of canine leishmaniasis in conjunctiva samples. DNA extraction was performed using SDS 20\% and PCR was performed using 13A/13B primers that amplify 120-bp of Leishmania kDNA. Of the 77 dogs analyzed, 50 (64.93\%) had ocular changes: 25 (32.47\%) dogs had periocular lesion, 41 (53.25\%) dogs had purulent eye discharge, and $17(22.08 \%)$ dogs had both signals. PCR was positive in 35 dogs $(45.45 \%)$, and there was no significant difference between dogs with and without ocular signals $(p=0.4074)$. PCR positivity was significant higher in dogs without periocular injury $(p=0.0018)$. Conjunctive $P C R$, a less invasive, fast, and painless collection technique, is indicated to complement the diagnosis, especially in dogs without periocular injury, independent of the presence of purulent eye discharge.
\end{abstract}

Keywords: Leishmania, conjunctiva, PCR.

\begin{abstract}
Resumo
O cão é o principal reservatório doméstico de Leishmania e também fonte de infecção para o vetor, constituindo um importante hospedeiro para a transmissão do parasita ao homem. A coleta não invasiva de amostras em swab para diagnóstico das leishmanioses tem sido uma alternativa promissora. Este estudo analisou a positividade da reação em cadeia da polimerase (PCR) para o diagnóstico de leishmaniose canina em amostras de conjuntiva. A extração do DNA foi realizada com SDS 20\%. A PCR foi realizada com primers 13A/13B que amplificam 120-pb do kDNA de Leishmania. Dos 77 cães analisados, 50 (64,93\%) tiveram alterações oculares; 25 (32,47\%) cães tiveram uma lesão periocular; 41 (53,25\%) tiveram secreção ocular purulenta e 17 (22,08\%) cães tiveram ambos os sinais. A PCR foi positiva em 35 cães $(45,45 \%)$ e não houve diferença significativa em cães com e sem sinais oculares $(p=0,4074)$. A positividade da PCR foi significativamente maior em cães sem lesão periocular $(p=0,0018)$. PCR em conjuntiva, uma técnica de coleta menos invasiva, rápida e indolor, é indicada para complementar o diagnóstico, principalmente em cães sem lesão periocular, independentemente da presença de secreção ocular purulenta.
\end{abstract}

Palavras-chave: Leishmania, conjuntiva, PCR.

Received May 15, 2021. Accepted June 1, 2021.

*Corresponding author: Manoel Sebastião da Costa Lima Junior, Herintha Coeto Neitzke-Abreu. E-mail: manoel.lima@cpqam.fiocruz.br, herinthaabreu@ufgd.edu.br 


\section{Introduction}

The second parasitic disease that causes most deaths worldwide is leishmaniasis complex. It is endemic in Asia, Africa, the American, and the Mediterranean region. In the American continent, it is mainly found in the tropical and subtropical regions (Horimoto \& Costa, 2009). The transmission of leishmaniasis occurs through the bite of female dipterans of the subfamily Phlebotominae.

As dogs are considered the main domestic reservoirs, a reliable, accurate, and specific diagnostic method for detecting parasites is crucial (Molina et al., 1994). Parasitic DNA can be detected in a broad range of clinical specimens, such as bone marrow, lymph node aspiration, and liver, kidney, or other viscera biopsies (Perez, 2015). However, these samples are obtained by invasive and painful procedures.

Serological tests are widely used; however, these tests have limitations in diagnosis as they lack sensitivity and can generate false results in dogs with clinical disease. The combination of enzyme-linked immunosorbent assay (ELISA) and dual path platform (DPPTM) significantly improved the sensitivity and specificity (Gomes et al., 2008). Molecular methods such as polymerase chain reaction (PCR) are highly sensitive and specific for detecting the parasite's DNA, regardless of the disease stage (Oliveira et al., 2006). The need for effective methods capable of detecting the parasite by using material from the less invasive collections allows the animals to be diagnosed more painlessly. Thus, the current study analyzes the positivity of conjunctival swab PCR in the diagnosis of Canine Leishmaniasis (LeishCan) in seropositive dogs for visceral leishmaniasis.

\section{Material and Methods}

This study was reviewed and approved by the Ethics Committee on the Use of Animals of the Universidade Federal da Grande Dourados (protocol number 27/2016). Written informed consent was obtained from the dog owners.

Dogs diagnosed with LeishCan in serological tests (DPPTM rapid test and ELISA) were sent to the Control Center of Zoonoses (CCZ) in the city of Campo Grande/Mato Grosso do Sul state for euthanasia from May to July 2016.

The veterinarian at $\mathrm{CCZ}$, before the collection of samples, performed the evaluation of clinical signals and the characterization of the animals regarding gender (male and female), age [puppies (up to one year old) and young adults (2-4 years old)], and size [small (below 40 centimeter), medium (40 to 60 centimeter), and large (over 60 centimeter)]. Silveira et al. (2018) analyzed the dogs, along with the samples collected from other animals in the same place and period and reported the data. The samples were collected from the conjunctiva of the right and left eye of each dog using a sterile cotton swab.

The DNA was obtained using SDS $20 \%$ and resuspended in $50 \mu \mathrm{L}$ of TE buffer (10 mM TRIS; 1 mM EDTA; pH 8.0) according to Neitzke-Abreu et al. (2020). For each extraction, a positive control [dog blood without leishmaniasis plus $10^{4}$ promastigotes Leishmania (Leishmania) infantum] and a negative amplification control (dog blood without leishmaniasis) were included.

After obtaining the DNA, the samples were subjected to PCR using primers 13A (5-GTG GGG GAG GGG CGT TCT-3) and 13B (5-ATT TTA CAC CAA CCC CCA GTT-3) (Rodgers et al., 1990), which were used to amplify 120-bp of Leishmania spp. A negative control (water) and two positive controls [DNA Leishmania (Viannia) braziliensis and Leishmania (Leishmania) amazonensis] were added.

Samples with negative $P C R$ results for Leishmania were subjected to a new reaction using $\beta$-actin $F\left(5^{\prime}\right.$-CTT CTA CAA CGA GCT GCG CG-3') and $\beta$-actin R (5'-TCA TGA GGT AGT CGG TCA GG-3') primers described by Silveira et al. (2018), were directed to amplify a 307-bp fragment present in the $\beta$-actin gene Canis familiaris.

The proportions were analyzed using OpenEpi version 3.01, with a confidence interval (CI) of 95\% and the Chi-square test was used to compare PCR positivity.

\section{Results}

Seventy-seven dogs of both genders and different ages and sizes were enrolled in this study. Of the dogs analyzed, 64.93\% (50/77) (CI 95\%, 53.80-74.65) had eye signals, 32.47\% (25/77) (CI 95\%, 23.06-43.54) had periocular injury, 53.25\% (41/77) (CI 95\%, 42.22-63.97) had purulent eye discharge and 22.08\% (17/77) (CI 95\%, 14.27-32.54) had periocular lesion with purulent eye discharge.

PCR was positive in $45.45 \%$ (35/77) (CI 95\%, 34.81-56.53). There was no significant difference in PCR positivity in females [53.49\% (23/43) (CI 95\%, 38.66-67.92)] and males [36.67\% (11/30) (Cl 95\%, 21.02-54.78)] $(p=0.1563)$, 
and one dogs (1/4) with positive PCR had no information about gender. Regarding size, PCR was positive in 66.67\% (6/9) (Cl 95\%, 33.24-90.73) of large dogs, 29.03\% (9/31) (Cl 95\%, 15.18-46.64) in medium dogs, and 57.14\% (20/35) (Cl 95\%, 40.50-72.65) in small dogs. There was a significant difference between medium and large dogs $(p=0.0172)$, and between medium and small dogs $(p=0.0216)$, while between small and large dogs there was no significant difference $(p=0.3513)$. Regarding age, PCR was positive in $47.06 \%(8 / 17)(C l 95 \%, 24.78-70.27)$ of puppies, in $44.83 \%(26 / 58)(C I 95 \%, 32.44-57.72)$ of young adults $(p=0.8709)$, and in one dog $(1 / 2)$ with positive PCR had no age identification.

There was no significant difference in the results of PCR in dogs with or without ocular signals $(p=0.4074)$. PCR positivity for dogs with some ocular signal was $42.0 \%$ (21/50) (CI 95\%, 28.96-55.95), positivity in dogs with periocular injury was $20.0 \%$ (5/25) (CI 95\%, 8.86-39.13), dogs with purulent secretion were $46.34 \%$ (19/41) (CI 95\%, 32.06-61.25) and dogs with both signals were $23.53 \%$ (4/17) (CI 95\%, 9.56-47.26). Only one dog presented with corneal opacity and was negative for PCR. Considering only periocular injury, the positivity of the PCR was significant higher in dogs without periocular injury $(p=0.0018)$. In addition, 58.0\% (29/50) $(C I 95 \%, 44.05-71.04)$ dogs had eye signals but had negative PCR results, 51.85\% (14/27) (CI 95\%, 33.31-70.02) dogs had no eye signals but had positive PCR, and $48.15 \%$ (13/27) (Cl 95\%, 29.98-66.69) dogs had no eye signals and negative PCR.

\section{Discussion}

Although our results demonstrated no significant difference in PCR in dogs with eye signals, studies have demonstrated a significant association with the presence of clinical signs and positive PCR in conjunctiva samples in swab, blood, bone marrow and skin (Ferreira et al., 2012; Pereira et al., 2016). Dermatological changes, weight loss, lymphadenopathy, onychogryphosis and hepatosplenomegaly have been reported in all dogs with a positive result in conjunctive PCR. Ocular abnormalities in LeishCan are common (Penã et al., 2000; Brito et al., 2010; Baneth et al., 2008) and result from the immune response due to infection Leishmania, as the conjunctiva is one of the first lymphoid centers assets (Brito et al., 2010). The report on ocular parasitism and tissue tropism (Geisweid et al., 2013) highlights the importance of studies in canine conjunctiva for DNA research by Leishmania spp.

All animals had more than five clinical signals related to the development of the disease. In this study most animals had ocular signs (64.93\%). Purulent eye discharge followed by the periocular injury was the most frequent finding of the study. Ocular signs, including keratoconjunctivitis, uveitis, and blepharoconjunctivitis, have been detected in dogs with Leishmania sp. (Ciaramella et al. 1997; Brito et al., 2010; Baneth et al., 2008). This indicating the possibility of parasites in this tissue.

The absence between the age and gender with the prevalence of LeishCan evidenced in our results corroborates with other results (Azevedo et al., 2008). However, the greater positivity in medium-sized animals in our results differs from the scientific literature that reports the greater susceptibility of large and giant breeds due to the greater body surface favoring the bite of sandflies (Gálvez et al., 2010).

PCR positivity was not high in this study (45.45\%). We used primers for the Leishmania genus to detect any species, although cases of LeishCan caused by another species than L. infantum are rare. PCR is less sensitive than serological tests such as ELISA and Indirect Immunofluorescence Reaction (IIF) (Duthie et al., 2018), due the abundance of anti-Leishmania antibodies is greater than Leishmania genetic material. In addition, factors related to the method of collection, conservation and processing of samples can influence the positivity of PCR. In serology inconclusive cases (Santarém et al., 2020), molecular tests can assist in the diagnosis of LeishCan, complementing serological tests.

In our study, PCR was positive in $42.0 \%$ of dogs had ocular signals. One study showed positive conjunctival cytology for Leishmania even with negative direct parasitological examination at on lymph node and marrow samples (Santos et al., 2017). Studies have reported high positivity in the conjunctiva PCR in symptomatic animals (Ferreira et al., 2012; Pereira et al., 2016). Conjunctiva cytological investigations for amastigote research on Leishmania also demonstrated good positivity (Barbosa et al., 2012). The significant positivity in dogs without periocular injury can be explained by recent infection and the immune response. Ferreira et al. (2013) found DNA L. infantum in dogs that did not present conjunctival lesions, emphasizing the practicality and potential for diagnosis. These data indicate a significant relevance of the presence of the parasite in conjunctiva, even without tissue damage.

Using a part of the same dogs, PCR positivity was higher in blood (84.75\%) (Silveira et al., 2018) and ear blood (70.90\%) (Neitzke-Abreu et al., 2020) than the conjunctiva swab (45.45\%), but this, in addition to being a less invasive collection allows us to obtain purer DNA and less discomfort for the animal. Other authors have shown 
that PCR is superior to blood (Lombardo et al., 2012; Pereira et al., 2016). The comparison in nasal and conjunctival swabs showed no difference in terms of parasitic load and was close to detection in skin biopsy, but lower than bone marrow samples (Ferreira et al., 2013). This maybe is due to a positive synergy between the DNA extraction technique and the primers used.

PCR was negative in $58.0 \%$ (29/50) dogs had ocular signals, and in $48.15 \%$ (13/27) dogs had no ocular signals. This can indicate decreased parasitic load but show the limitation in using the conjunctiva for the diagnosis of LeishCan. Adequate cellular immune response in dogs is considered to control the spread of the pathogen in tissues such as mucous membranes and skin (Solano-Gallego et al., 2001). Ocular changes can occur due to the immune response, without the local presence of parasites. This shows the need for further studies to improve the diagnosis and understanding of ocular changes in dogs produced by Leishmania.

Although some authors affirm the significant existence of parasitic load in the ocular conjunctiva, our results did not show a good result of PCR in conjunctiva swab. The importance of exploring a less invasive, quick, and painless collection technique, in contrast to the methods for collecting samples from bone marrow and lymph nodes, helps reduce the suffering of symptomatic dogs in a weak and extremely fragile state. Conjunctive PCR is indicated in to complement the diagnosis, especially in dogs without periocular injury, independent of the presence of purulent eye discharge.

\section{Acknowledgements}

The authors would like to thank the and Universidade Federal da Grande Dourados (UFGD) for the English review and financial support.

\section{References}

Azevedo MAA, Dias AKK, Paula HB, Perri SHV, Nunes CM. Avaliação da leishmaniose visceral canina em Poxoréo, Estado do Mato Grosso, Brazil. Rev Bras Parasitol Vet 2008; 17(3): 123-127. http://dx.doi.org/10.1590/S1984-29612008000300001. PMid:19245756.

Baneth G, Koutinas AF, Solano-Gallego L, Bourdeau P, Ferrer L. Canine leishmaniosis - new concepts and insights on an expanding zoonosis: part one. Trends Parasitol 2008; 24(7): 324-330. http://dx.doi.org/10.1016/j.pt.2008.04.001. PMid:18514028.

Barbosa VT, Silva MAG, Sousa MG, Gering AP, Santos HD, Laus JL. Detecção de formas amastigotas em exame parasitológico de esfregaço obtido a partir de suabe conjuntival de cães com leishmaniose visceral. Arq Bras Med Vet Zootec 2012; 64(6): 14651470. http://dx.doi.org/10.1590/S0102-09352012000600009.

Brito FLC, Laus JL, Tafuri WL, Figueiredo MM, Silva AV Jr, Maia FCL, et al. Histopathological findings and detection of parasites in the eyes of dogs infected naturally with Leishmania chagasi. Cienc Rural 2010; 40(5): 1141-1147. http://dx.doi.org/10.1590/ S0103-84782010005000079.

Ciaramella P, Oliva G, Luna RD, Gradoni L, Ambrosio R, Cortese L, et al. A retrospective clinical study of canine leishmaniasis in 150 dogs naturally infected by Leishmania infantum. Vet Rec 1997; 141(21): 539-543. http://dx.doi.org/10.1136/vr.141.21.539. PMid:9413121.

Duthie MS, Lison A, Courtenay O. Advances toward diagnostic tools for managing zoonotic visceral Leishmaniasis. Trends Parasitol 2018; 34(10): 881-890. http://dx.doi.org/10.1016/j.pt.2018.07.012. PMid:30131210.

Ferreira SA, Almeida GG, Silva SO, Vogas GP, Fujiwara RT, De Andrade ASR, et al. Nasal, oral and ear swabs for canine visceral leishmaniasis diagnosis: new practical approaches for detection of Leishmania infantum DNA. PLoS Neg/ Trop Dis 2013; 7(4): e2150. http://dx.doi.org/10.1371/journal.pntd.0002150. PMid:23593518.

Ferreira SA, Leite RS, Ituassu LT, Almeida GG, Souza DM, Fujiwara RT, et al. Canine skin and conjunctival swab samples for the detection and quantification of Leishmania infantum DNA in an endemic urban area in Brazil. PLoS Neg/ Trop Dis 2012; 6(4): e1596. http://dx.doi.org/10.1371/journal.pntd.0001596. PMid:22506084.

Gálvez R, Miró G, Descalzo MA, Nieto J, Dado D, Martín O, et al. Emerging trends in the seroprevalence of canine leishmaniosis in the Madrid region (central Spain). Vet Parasitol 2010; 169(3-4): 327-334. http://dx.doi.org/10.1016/j.vetpar.2009.11.025. PMid:20031330.

Geisweid K, Weber K, Sauter-Louis C, Hartmann K. Evaluation of a conjunctival swab polymerase chain reaction for the detection of Leishmania infantum in dogs in a non-endemic area. Vet J 2013; 198(1): 187-192. http://dx.doi.org/10.1016/j.tvjl.2013.07.025. PMid:23993391. 
Gomes YM, Paiva Cavalcanti M, Lira RA, Abath FGC, Alves LC. Diagnosis of canine visceral leishmaniasis: biotechnological advances. Vet J 2008; 175(1): 45-52. http://dx.doi.org/10.1016/j.tvjl.2006.10.019. PMid:17150389.

Horimoto AMC, Costa IP. Frequência de autoanticorpos e dosagem de complemento sérico em pacientes com diagnóstico de leishmaniose cutânea ou visceral. Rev Bras Reumato/ 2009; 49(5): 529-546. http://dx.doi.org/10.1590/S0482-50042009000500005.

Lombardo G, Pennisi MG, Lupo T, Migliazzo A, Capri A, Solano-Gallego L. Detection of Leishmania infantum DNA by real-time PCR in canine oral and conjunctival swabs and comparison with other diagnostic techniques. Vet Parasito/ 2012; 184(1): 10-17. http://dx.doi.org/10.1016/j.vetpar.2011.08.010. PMid:21906883.

Molina R, Amela C, Nieto J, San-Andrés M, González F, Castillo JA, et al. Infectivity of dogs naturally infected with Leishmania infantum to colonized Phlebotomus perniciosus. Trans R Soc Trop Med Hyg 1994; 88(4): 491-493. http://dx.doi.org/10.1016/00359203(94)90446-4. PMid:7570854.

Neitzke-Abreu HC, Vieira VBD, Silveira APS, Batalini LS, Gnutzmann LV, Castro SO, et al. Diagnosis of Canine Leishmaniasis using ear blood PCR in Region of Brazil. Adv Anim Vet Sci 2020; 8(2): 157-160. http://dx.doi.org/10.17582/journal.aavs/2020/8.2.157.160.

Oliveira ALL, Paniago AMM, Dorval MEC, Oshiro ET, Leal CR, Sanches M, et al. Foco emergente de leishmaniose visceral em Mato Grosso do Sul. Rev Soc Bras Med Trop 2006; 39(5): 446-450. http://dx.doi.org/10.1590/S0037-86822006000500005. PMid:17160321.

Peña MT, Roura X, Davidson MG. Ocular and periocular manifestations of leishmaniasis in dog: 105 cases (1993-1998). Vet Ophthalmol 2000; 3(1): 35-41. http://dx.doi.org/10.1046/j.1463-5224.2000.00106.x. PMid:11397281.

Pereira VF, Benassi JC, Starke-Buzetti WA, Silva DT, Ferreira HL, Keid LB, et al. Detection of canine visceral leishmaniasis by conjunctival swab PCR. Rev Soc Bras Med Trop 2016; 49(1): 104-106. http://dx.doi.org/10.1590/0037-8682-0191-2015. PMid:27163572.

Perez TD. The importance of domestic dogs as reservoirs for Trypanosoma cruzi and Leishmania spp. in the rural area of the municipality of São João do Piauí (PI) [Dissertation]. Rio de Janeiro: Instituto Oswaldo Cruz; 2015.

Rodgers MR, Popper SJ, Wirth DF. Amplification of kinetoplast DNA as a tool in the detection and diagnosis of Leishmania. Exp Parasitol 1990; 71(3): 267-275. http://dx.doi.org/10.1016/0014-4894(90)90031-7. PMid:2170165.

Santarém N, Sousa S, Amorim CG, de Carvalho NL, de Carvalho HL, Felgueiras Ó, et al. Challenges in the serological evaluation of dogs clinically suspect for canine leishmaniasis. Sci Rep 2020; 10(1): 3099. http://dx.doi.org/10.1038/s41598-020-60067-6. PMid:32080327.

Santos F, Borges OMM, Carvalho CB, Tanikawa A, Dantas AM No, Silva NMR, et al. Presença de Leishmania spp. na conjuntiva de um cão não reativo para testes parasitológicos em linfonodos e medula óssea - relato de caso. Jorn Inter Bioc 2017; 2(2): 33-37.

Silveira APS, Vieira VBD, Batalini LS, Carmo SBD, Friozi E, Arruda EJ, et al. PCR sensitivity of peripheral blood of dogs co-infected with Leishmania spp. and Ehrlichia spp. in endemic area of Brazil. Rev Soc Bras Med Trop 2018; 51(6): 843-847. http://dx.doi. org/10.1590/0037-8682-0040-2018. PMid:30517541.

Solano-Gallego L, Morell P, Arboix M, Alberola J, Ferrer L. Prevalence of Leishmania infantum infection in dogs living in an area of canine leishmaniasis endemicity using PCR on several tissues and serology. J Clin Microbiol 2001; 39(2): 560-563. http://dx.doi. org/10.1128/JCM.39.2.560-563.2001. PMid:11158106. 